\title{
Työpaikalla oppimisen toimintakäytäntöjä on selkeytettävä
}

\section{Laitoshuoltajaopiskelijat työssä oppimassa}

\author{
Työpaikalla tapahtuvassa oppimisessa olennaisia ovat \\ oppimiskäsitysten tunnistaminen, vuorovaikutuksen ja ohjauksen \\ laatu sekä oppilaitoksen ja työpaikan välinen yhteistyö.
}

KUN TUTKIN VUONNA 2017 valmistuneessa väitöstutkimuksessani, millaisia käsityksiä ja kokemuksia laitoshuoltajaopiskelijoilla on työpaikalla tapahtuvasta oppimisesta, esiin nousi kiinnostava dilemma. Kävi ilmi, että oppiminen työpaikalla edistää ammatillisten taitojen kasvua, mutta ei takaa syvällistä oppimista eikä ammatti-identiteetin kehittymistä. Tutkimus on erityisen ajankohtainen, sillä vuoden 2018 alussa voimaan tullut ammatillista koulutusta koskeva laki siirtää oppimisen yhä enemmän työpaikoille.

Ammatilliseen koulutukseen sopii sanonta "työ tekijännsä opettaa", sillä oppilaitoksessa opiskelun ohella opiskelijan on opittava ammattitaito tekemällä oman alansa töitä työpaikalla. Sanonnan mukainen ajattelumalli heijastuu vuosituhannen vaihteen koulutuspoliittisissa ratkaisuissa, joissa suomalaista ammatillista koulutusta on kehitetty elinkeinoelämän tarpeiden näkökulmasta. Sysäyksen kehittämistyölle ovat antaneet työelämässä tapahtuneet muutokset, jotka edellyttävät ihmisiltä joustavuutta ja kykyä elinikäiseen oppimiseen (Räty 2016). Ammatillisen koulutuksen uudistuksen myötä työelämän merkitys osaamisen hankkimisessa on korostunut. Osa ammattitaidosta voidaan hankkia kokonaan työpaikoilla, ja aiemmin hankittu osaaminen voidaan tunnustaa osaksi ammatillista tutkintoa. 


\section{TYÖYHTEISÖSSÄ OPISKELIJA}

KASVAA KULTTUURIN JA

YHTEISÖN JÄSENIKSI

SEK ̈̈ AMMATIN HARJOITTAJAKSI.

Vuoden 2017 laki ammatillisesta koulutuksesta uudistaa koulutuksen tutkintojärjestelmää, rahoitusta ja ohjausta (2017/531). Tavoite on nostaa työllistymisastetta ja nopeuttaa valmistuneiden työllistymistä parantamalla koulutuksen työelämävastaavuutta sekä oppilaitoksen ja työelämän välistä yhteistyötä. Pedagogista toimintaa ohjaa osaamisperusteisuus, jossa korostuvat tietojen, taitojen ja asenteiden samanaikainen oppiminen ja niiden yhdistyminen osaamiseksi aidossa työelämän tilanteessa (Nissilä, Karjalainen, Koukkari \& Kepanen 2015). Käytännössä uudistus lisää työpaikalla tapahtuvaa oppimista (Hallituksen esitys 2017).

'Työpaikalla tapahtuva oppiminen' on käsite, joka kuvaa ammatilliseen koulutukseen sisältyvää työpaikalla oppimista. Termi huomioi laajasti kaikki työhön kuuluvat oppimisen muodot, kuten ohjatun, epävirallisen, arkisen ja oppilaitosmuotoisen tietopohjaisen oppimisen. (Samppala 2017.) Opiskelija oppii ammattinsa kokemuksen kautta, tekemällä työtä yhdessä kokeneemman ammatinharjoittajan kanssa.

Osallistuminen työyhteisön toimintaan ei muokkaa ainoastaan opiskelijoiden tietoja ja taitoja, vaan opiskelijat kasvavat tietyn kulttuurin ja yhteisön jäseniksi sekä ammatin harjoittajiksi (Lave 1996). Opiskelu ammatillisessa yhteisössä on prosessi, johon sisältyy identiteetin muodostuminen (Vågan 2011), käsitys siitä, millaiseksi ihminen kokee itsensä suhteessa työhön ja ammatillisuuteen, mihin kokee samastuvansa sekä mihin hän työssään ja ammatissaan sitoutuu (Eteläpelto 2007).

Työpaikalla tapahtuva oppiminen yhdistää oppimisen eri osapuolet - opiskelijat ja ohjaajat - yhteisen päämäärän, opiskelijan oppimisen, äärelle. Oppimisessa on olennaista opiskelijan aktiivinen osallistuminen työyhteisön toimintaan, oppimista tukeva ohjaus ja yhteistyö eri toimijoiden kesken. Lisäksi on tärkeää huolehtia työtehtävien monipuolisuudesta, kokemusten vaihdosta ja opittujen asioiden reflektoinnista, sillä ne lisäävät opiskelijan toimintakykyä. (Hulkari 2006.)

Työpaikalla tapahtuva oppiminen on ollut 2000-luvulla tutkijoiden mielenkiinnon kohteena. Useat viimeaikaiset tutkimukset ovat osoittaneet, ettei työpaikalla oppiminen välttämättä tue opiskelijoiden oppimista. Sen ongelmia ovat ohjauksen ja vuorovaikutuksen puute (Rintala, Mikkonen, Pylväs, Nokelainen \& Postareff 2015), ohjauksen laadun vaihtelut (Filliettaz 2011) ja vastuun puuttuminen yksittäisen opiskelijan oppimisesta (Virtanen \& Collin 2007).

Lisäksi ammatillisen koulutuksen kehittämistä tutkineet Karin Filander ja Esa Jokinen (2008) ovat kritisoineet sitä, että työpaikalla oppiminen kaventaa yleisemmän ammatillisessa koulutuksessa opitun tietotaidon työpaikkakohtaiseksi käytännön taidoksi.

Omat havaintoni tutkijana ja opettajana ovat samansuuntaiset edellä kuvattujen tutkimusten kanssa. Työskennellessäni 20 vuoden ajan puhtausalan asiantuntija-, johto- ja koulutustehtävissä olen huomannut, että ohjaajat suhtautuvat opiskelijoihin vaihtelevasti, ja myös oppimisen laadussa on eroja.

\section{KÄSITYKSIÄ JA KOKEMUKSIA TYÖPAIKALLA TAPAHTUVASTA OPPIMISESTA}

Väitöskirjatutkimuksessani selvitin työpaikalla tapahtuvan oppimisen käsityksiä ja merkittäviä kokemuksia. Ymmärrän käsityksen fenomenografisen tutkijan ja kehittäjän Ference Martonin (1996) tavoin näkemykseksi henkilökohtaisesta ilmiötä koskevasta kokemuksesta. Minua kiinnostivat erityisesti käsitysten vaihtelut, yhtäläisyydet ja erot. Lisäksi tutkin erittäin merkittäviä oppimiskokemuksia. Hyödynsin critical incident -tekniikkaa, jonka perustajan John Flanaganin (1954) mukaan merkittävät tapaukset ovat kokemuksia, jotka ovat jääneet vahvasti kokijan mieleen. Olin kiinnostunut erittäin onnistuneista tai epäonnistuneista oppimiskokemuksista, jotka olivat työpaikalla tapahtuvan oppimisen kannalta kriittisiä, jotkin positiivisia ja toiset negatiivisia tapahtumia.

Toteutin tutkimukseni laadullisen tutkimusotteen avulla, ja nojasin tulkitsevaan paradigmaan, jolle 


\section{YKSIK ̈̈̈̈N TYÖPAIKKAOHJAAJA}

EI TUONUT ESILLE

\section{AMMATILLISTA IDENTITEETTI $\ddot{A}$.}

on ominaista, että ilmiöitä pyritään ymmärtämään inhimillisen kokemuksen kautta (Hammersley 2013). Tutkimusasetelma oli ennen-jälkeen-tutkimus (Jensen \& Rodgers 2001). Tarkastelin opiskelijoiden käsityksiä ja kokemuksia työpaikalla tapahtuvasta oppimisesta koulutuksen alussa ja lopussa. Mielenkiintoni kohdistui siihen, miten opiskelijoiden käsitykset ja kokemukset muuttuivat oppimisprosessin aikana.

Empiirisen aineiston keräsin Hämeen seudulla vuosina 2011-2012. Tutkimusaineisto koostui 57 haastattelusta, 36 oppimispäiväkirjasta ja kenttäpäiväkirjamuistiinpanoistani. Haastatteluaineistosta muodostui tutkimukseni pääaineisto, sillä omista kokemuksista kirjoittaminen osoittautui opiskelijoille vaikeaksi, ja osa jätti palauttamatta oppimispäiväkirjansa opintojen lopussa. Haastatellut olivat ammatissa toimivia $(\mathrm{N}=8)$ ja työpaikkaa hakevia $(\mathrm{N}=16)$ laitoshuoltajaopiskelijoita sekä heidän ohjauksestaan vastanneita opetushenkilöitä $(\mathrm{N}=4)$ ja työpaikkaohjaajia $(\mathrm{N}=6)$. Opiskelijat olivat iältään 27-58-vuotiaita, ja heidän keski-ikänsä oli 44 vuotta. Oppimispaikkoina olivat lähialueen työpaikat, joissa opiskelijat oppivat viisi tutkinnon osaa vajaan vuoden kestäneen koulutuksen aikana.

Tähän mennessä on tehty vain vähän empiiristä tutkimusta siitä, miten ammatilliset opiskelijat kokevat ja käsittävät työpaikalla tapahtuvan oppimisen. Tutkimuksen näkökulma on tärkeä, sillä vähäiset opiskelukokemukset saattavat vaikuttaa oppimiseen ja opinnoista selviämiseen. Tutkimus on hyödyksi niin alan opiskelijoille, oppilaitoksille, opettajankouluttajille, työelämän edustajille ja tutkijoille kuin kaikille ammatillisesta kasvusta ja työssäoppimisjärjestelmän kehittämisestä kiinnostuneille. Sen avulla voidaan kehittää oppimiskäytäntöjä, joilla on merkitystä opiskelijan hyvinvoinnille ja opintomenestykselle

\section{MITÄ TYÖPAIKALLA OPITAAN?}

Opiskelijoiden käsityksissä työpaikalla tapahtuvasta oppimisesta painottuivat ammattialan tietojen ja taitojen oppiminen. Oppimista työpaikalla kuvattiin uusien taitojen ja työssä tarvittavan rutiinin oppimiseksi sekä koulussa opittujen tietojen soveltamiseksi käytännön työelämässä.

”Työssä opitaan uusia asioita, kuten koneiden käyttöä, menetelmiä, ateriapalvelua ja poislähtevien potilaiden sänkyjen petausta ja kaikkia tällaista, mitä en ole aikaisemmin tehnyt. [--] on sitä, että täällä koulussa opitaan tiettyjä asioita teoriassa, joita voi sitten käytännössä harjoittaa. [--] On just sitä rutiinin oppimista, et osaat tehdä sitä työtä."

Tietotaidon oppimista on ennenkin pidetty tärkeänä työpaikalla tapahtuvassa oppimisessa (Virkkula, 2014; Virtanen \& Collin 2007). Esimerkiksi työssäoppimista ammatillisessa koulutuksessa tutkineet Anne Virtanen ja Kaija Collin (2007) ovat todenneet opiskelijoiden ammatillisten taitojen vahvistuneen työssäoppimisen aikana.

Tutkimukseni ei kuitenkaan vahvistanut aikaisemmissa tutkimuksissa esiin noussutta ammatillisen identiteetin tai yhteisöllisyyden vahvistumisesta työpaikkajaksojen aikana. Opiskelijoiden sosiaalisen identiteetin muodostumista tutkineen André Våganin (2011) sekä käytäntöyhteisöjen toimintaa tutkineiden Jean Laven ja Etienne Wengerin (1991) mukaan oppiminen työn kontekstissa muokkaa opiskelijan persoonaa ja ammatillista yhteenkuuluvuutta.

Vågan (2011) on todennut, että ammatin oppiminen ja identiteetti muodostuvat kumpikin opiskeluaikana. Tutkimukseeni osallistuneista 24 opiskelijasta vain kolme käsitti oppimisen ammatillisen identiteetin vahvistamiseksi. Vastaavasti yksikään työpaikkaohjaajista ei tuonut esille ammatillista identiteettiä.

Ammatillisen identiteetin kehittymistä edistävät ohjaajien asenne, tuki ja kannustus (vrt. Hulkari 2006) sekä ohjaussuhteen pysyvyys (Tuomi-Gröhn 2001). Tutkimuksessani työpaikkaohjaajien suhtautuminen opiskelijoihin vaihteli. Parhaimmillaan opiskelijan ja ohjaajan välinen vuorovaikutus oli vastavuoroista, mikä edisti opiskelijoiden ammatillisen identiteetin 
kehittymistä. Huonoimmillaan vuorovaikutusta ei ollut lainkaan, tai se oli kielteistä, mikä heikensi opiskelijoiden voimavaroja ja sitoutumista alaan.

Ohjaussuhteen pysyvyys ei toteutunut tutkimuksessani, sillä valtaosa opiskelijoista toteutti työssäoppimisjakson neljässä tai viidessä eri työpaikassa oppimisprosessinsa aikana. Lisäksi sitoutumista alaan esti se, että sekä opiskelijat että ohjaajat käsittivät oppimisen enemmän yksilöllisenä kuin yhteisöllisenä prosessina. Esimerkiksi ongelmatilanteissa opiskelijoita kannustettiin omakohtaiseen ongelmanratkaisuun sen sijaan, että heitä olisi ohjattu ratkaisemaan asioita työyhteisön kanssa.

Ammatillisen koulutuksen uudistuksen myötä oppiminen siirtyy yhä enemmän työpaikoille, tutkinnot laaja-alaistuvat, ja opiskelijoiden valinnaisuus lisääntyy. He voivat suorittaa oppimisen tutkinnon osien mukaan useissa eri työpaikoissa (Hallituksen esitys 2017). Yhteisöllisyyden tukeminen on yhä ajankohtaisempaa, jotta ammatillinen identiteetti ja sitoutuminen ammatilliseen yhteisöön kehittyisivät jo opiskeluaikana.

\section{TYÖPAIKALLA TAPAHTUVAN OPPIMISEN DILEMMA}

Opiskelijoiden oppimiskäsityksiä tutkimalla tulkitsin opiskelijoiden oppimisen laatua työpaikan kontekstissa. Laitoshuoltajaopiskelijat oppivat pääsääntöisesti mallioppimalla, jolloin ohjaaja näytti, miten työ tehdään oikein. Mallioppimisen taustalla olevan behavioristisen oppimiskäsityksen mukaan oppiminen tapahtuu jäljittelemällä, havainnoimalla ja harjoittelemalla (Jordan, Carlile \& Stack 2008). Passiivinen suhtautuminen omaan oppimiseen ilmeni erityisesti keskusteluissa, jotka koskivat oppijan roolia oppimistapahtumassa. Vastuu oppimisesta kuului opiskelijoiden mukaan oppimisen ohjaajille, eli opettajille ja työpaikkaohjaajille.

"Oppiminen on sitä, että opettelee asiat ulkoa. [-- Sillai mä opin, kun mä teen. Toistoja tarvitaan paljon. [--] Oppiminen on sitä, että ohjaaja opastaa ja kertoo niitä asioita ja tekee kaiken, mitä kuuluu siihen. [--] Opiskelijana ei tarvitse ottaa täyttä vastuuta vielä. Kyllä se henkilökunta siellä työssä ja opettajat ovat vastuussa, että opiskelija oppii työpaikalla."

Laitoshuoltajaopiskelijoiden oppimiskäsitykset pysyivät behavioristisina koko koulutuksen ajan. Opiskelijat keskittyivät pelkästään toimintatapojen muutokseen, ja oppiminen eteni suorituspainotteisesti ohjaajan mallia seuraten. Myös työpaikkaohjaajien oppimiskäsitykset olivat valtaosin behavioristisia. Sitä vastoin opetushenkilöstön ajattelussa ilmeni konstruktivistisen oppimiskäsityksen piirteitä. Opettajat käsittivät oppijan roolin aktiivisena ja tarkastelivat oppimista kasvun ja kehittymisen näkökulmasta. Tulokseni opiskelijoiden ja työpaikkaohjaajien oppimista koskevista käsityksistä ovat ristiriidassa nykyisinkin varsin yleisen konstruktivistisen oppimiskäsityksen kanssa. Siinä korostetaan oppijan aktiivista roolia tiedon rakentajana (Rauste-von Wright, von Wright \& Soini 2003).

Behavioristisen oppimiskäsityksen ongelma työpaikalla tapahtuvassa oppimisessa tulee esille tiedon siirtymisessä. Tieto siirtyy vain tilanteissa, joka sisältää samanlaisia toimintavirikkeitä kuin aiempi oppimistilanne (Tuomi-Gröhn 2001). Sen sijaan opitun soveltaminen uusissa ja muuttuvissa tilanteissa ei ole mahdollista, koska behavioristinen oppimiskäsitys ei edistä opiskelijoiden ajattelutaitojen kehittymistä (Jordan, Carlile \& Stack 2008).

Toisaalta on myönnettävä, että laitoshuoltajaopiskelijan koulutuksessa behavioristinen oppimiskäsitys voi paikoin edistääkin oppimista. Esimerkiksi teknisten taitojen oppimisessa jäljittely on nopea, mutta vain yksi tapa mallintaa koneiden ja välineiden käyttöä. Ainoaksi oppimismenetelmäksi behavioristinen oppimiskäsitys ei kuitenkaan sovellu, sillä se ei tarjoa välineitä monimutkaisten haasteiden ratkaisemiseen muuttuvassa työelämässä (vrt. Räty 2016). Laitoshuoltajaopiskelijoiden tulee oppia ratkaisemaan työhönsä kuuluvia ongelmatilanteita, tehdä päätöksiä itsenäisesti ja oma-aloitteisesti sekä toimia yhteistyössä muiden kanssa (Näyttötutkinnon perusteet 2013).

Työpaikalla tapahtuvaa oppimista koskevassa julkisessa diskurssissa (esim. Kinnunen 2018; Salusjärvi 2017) on toistuvasti tuotu esille huoli siitä, miten työorganisaatiot pystyvät vastaamaan nykyisiin 


\section{ULKOINEN MOTIVAATIO}

\section{HEIKENSI OHJAAJIEN}

HALUA OHJATA OPPIMISTA.

koulutuspoliittisiin ratkaisuihin. Filanderin ja Jokisen (2008) mukaan on epävarmaa, kykenevätkö työpaikat todella tarjoamaan ammatinopiskelijoiden tarvitsemia henkilö- ja tukiresursseja. Huoli on aiheellinen, sillä oppiminen työpaikalla ei tukenut opiskelijoiden kognitiivisia prosesseja (Samppala 2017). Työpaikalla tapahtuvan oppimisen näkökulmasta ohjaajien pedagogisilla taidoilla on merkitystä. Ajattelutaitojen kehittymistä edistää erityisesti dialoginen ohjaussuhde, joka auttaa opiskelijoita reflektoimaan omia kokemuksiaan (Ojanen 2000).

\section{MERKITTÄVÄT KOKEMUKSET SÄÄTELEVÄT OPPIMISTA}

Laitoshuoltajaopiskelijoiden oppimisen kannalta kriittisiä olivat tilanteet, joissa opiskelijoiden odotukset ja kokemukset oppimisesta eivät kohdanneet.

"Työssä oppiminen on sitä, että mä oon siinä työpisteessä ja mulle sanotaan, että nyt tehdään näin. [--] Kun sitten menin ensimmäistä kertaa työpisteeseen, niin ajattelin, että eikö mua perehdytetä ollenkaan. Olisin toivonut, että ihminen olisi ollut koko ajan näyttämässä, miten se työ tehdään. Tunsin itseni maalaiseksi, joka vain pyörii paikallaan. Mutta sitten kun kyseli, sai tietoa."

Odotusten ja kokemusten välistä ristiriitaa syntyi erityisesti sellaisissa tilanteissa, joissa opiskelijoiden ja ohjaajien oppimiskäsitykset poikkesivat toisistaan. Esimerkiksi behavioristisen oppimiskäsityksen omaksuneet opiskelijat odottivat ohjaajalta työsuoritteiden ulkoista ohjausta ja kokivat omatoimisuutta edellyttävän ohjauksen puutteelliseksi. Sen sijaan konstruktivistisen oppimiskäsityksen omaavat ohjaajat olettivat opiskelijoilta itseohjautuvuutta ja oma-aloitteisuutta. He tulkitsivat opiskelijoiden epäitsenäisen ja passiivisen roolin herkästi kiinnostuksen puutteeksi.
Ristiriitaa aiheutti myös opiskelijoiden suhtautuminen oppimiseen. Jotkut eivät olleet kiinnostuneista itse ammatin oppimisesta, mutta työvoimapoliittisen tuen saaminen oli heille tärkeää. Opiskelijoiden toimintaa säätelivät ulkoiset palkkiot, ja oppimisen tavoitteet olivat irrallaan heistä itsestään. Ulkoinen motivaatio näkyi muun muassa itseohjautuvuuden puutteena ja työstä kieltäytymisenä. Se heikensi ohjaajien halua ohjata oppimista sillä ohjaajien mukaan opiskelijoiden oppimismotivaatioon ei voinut vaikuttaa. Eräs ohjaaja kiteytti: "Se lähtee itsestä se oppiminen, jos ei halua oppia niin ei meijän kannata panostaa häneen enempää."

Ohjaajien käsitys siitä, ettei opiskelijan oppimismotivaation kasvua voida tukea on vastakkainen useiden aikaisempien (Hakkarainen, Lonka \& Lipponen 2004; Deci \& Ryan 1985) tutkimusten kanssa, joissa on todettu, ettei motivaatio ole synnynnäinen ominaisuus, vaan sen kehittämistä voidaan opetella. Ulkoinen motivaatio voi muuttua sisäiseksi motivaatioksi, mikäli sitä aktiivisesti ohjataan ja pidetään yllä.

Ongelmana ovat opiskelijoiden ja ohjaajien erilaiset oppimiskäsitykset sekä se, ettei opiskelijoilla ja ohjaajilla ollut välineitä ymmärtää omista käsityksistään poikkeavia oppimis- ja ohjaustapoja. Opiskelijan oppimiselle ensiarvoisen tärkeää on, että ohjaaja kykenee ymmärtämään erilaisia oppijoita ja suunnittelemaan ohjausta opiskelijan oppimistarpeet huomioiden.

\section{OPPIMISYMPÄRISTÖN JA OHJAUKSEN TAVOITTEET SELVIKSI}

Oppiminen työpaikalla lisäsi laitoshuoltajaopiskelijoiden ammatillisia tietoja ja taitoja ja edisti siten heidän ammatillista kehittymistään. Toisaalta behavioristisen oppimiskäsityksen omaavien opiskelijoiden oli vaikea soveltaa oppimaansa muuttuvissa työtilanteissa. Ongelmaksi muodostui se, miten varmistetaan opiskelijan itsenäinen osaaminen.

Oppiminen työpaikan kontekstissa ei tukenut opiskelijoiden ammatillisen identiteetin kehittymistä eikä sitoutumista alaan. Haasteelliseksi osoittautuivat ohjauksen laadun vaihtelut sekä oppilaitoksen ja työpaikan välisen vuorovaikutuksen puute. 
Ammatillisen koulutuksen uudistuksen myötä oppiminen toteutuu aiempaa enemmän työpaikoilla; yksilöllisiä opintopolkuja lisätään, ja ohjauksen resursseja vähennetään (Hallituksen esitys 2017). Ohjausresurssien väheneminen ei edistä oppilaitoksen, työelämän ja opiskelijan välistä vuorovaikutusta, joka on kuitenkin osa ammatillisen identiteetin rakentumista (vrt. Keisala 2012). Valinnaisuuden kasvattaminen herättää lisäksi kysymyksen, miten alalle hakeutuva opiskelija löytää uusista tutkinnon osista itselleen sopivimman koulutuspolun ja rakentaa ammatillisen osaamisen ja identiteetin. Tutkimustulokset ja koulutuspoliittiset ratkaisut ovat ristiriidassa keskenään. Tutkimuksen pohjalta ohjauksen resursseja tulee mieluummin lisätä kuin vähentää, ja tulee tähdätä työelämän opetusmenetelmien ja pedagogiikan kehittämiseen.

Ammatillisen koulutuksen reformissa korostuu osaamisperustaisuus. Koulutusta uudistettaessa ja kehitettäessä on kuitenkin tarpeen kysyä, miten opiskelijoiden oppimista voidaan tukea työpaikalla. Näkemykseni mukaan oppimisen mahdollisuuksia edistävät työpaikalla tapahtuvan oppimisen tavoitteiden selkeyttäminen, yhtenäistäminen ja läpinäkyvyys.

Työpaikkaohjaajien perehdyttämiseen on kiinnitettävä erityistä huomiota. Ammatilliset oppilaitokset voisivat esimerkiksi kehittää täydennyskoulutusta ja oppimateriaalia sekä tarjota työpaikkaohjaajille käytännön työkaluja ammatillisten opiskelijoiden syvällisen oppimisen tukemiseen. Kun ohjaajat tunnistavat opiskelijoidensa erilaisia oppimiskäsityksiä, he voivat yhä paremmin ymmärtää vuorovaikutustilanteiden moninaisuutta ja löytää monipuolisia sekä opiskelijoiden yksilöllisyyden huomioon ottavia näkökulmia oppimisprosessien ohjaamiseen.

Toinen tapa vahvistaa ammattiin kasvamista on kiinnittää huomiota opiskelijoiden oppimisprosessien tukemiseen työpaikan kontekstissa kehittämällä opiskelijoiden omaa aktiivisuutta ja metakognitiivisia taitoja. Lisäksi opiskelijoiden ammatillisen identiteetin rakentuminen edellyttää yhteisöllisyyden kasvua tukevia toimintakäytäntöjä, kuten pitkäaikaista ja rakentavaa ohjaussuhdetta, sekä työpaikan ja oppilaitoksen välistä kiinteää yhteistyötä (Vågan 2011; Tuomi-Gröhn 2001).

Kun vastuu oppimisesta siirtyy yhä enemmän työpaikoille, tarvitaan monipuolista keskustelua ja tutkimusta siitä, millainen aikuiskoulutus vastaa parhaiten nopeasti muuttuvan ja moninaistuvan työelämän ammatillisiin osaamistarpeisiin ja miten asiantuntijuuden kehittymistä voidaan tukea jo opiskeluaikana.

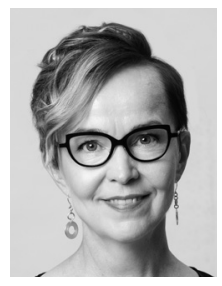

MARJA-LIISA SAMPPALA

FT, AO (kta)

lehtori

HAMK Ammatillinen

opettajakorkeakoulu 
Deci, E. L. \& Ryan, R. M. (1985). The general causality orientations scale: Self-determination in personality. Journal of Research in Personality 19 (2), 109-134.

Eteläpelto, A. (2007). Työidentiteetti ja subjektius rakenteiden ja toimijuuden ristiaallokossa. Teoksessa Eteläpelto, A., Collin, K. \& Saarinen, J. (toim.) Työ, identiteetti ja oppiminen. Helsinki: WSOY, 90-142.

Filander, K. \& Jokinen E. (2008). Kehittämisen pakko vai mahdollisuus? Teoksessa Heiskanen, T., Leinonen, M., Järvensivu, A. \& Aho, S. (toim.) Kohti uutta työelämää? Tutkimuksen näköala työelämän kehitykseen. Tampere: Tampere University Press, 196-214.

Filliettaz, L. (2011). Collective guidance at work: a resource for apprentices? Journal of Vocational Education and Training 63 (3), 485-504.

Flanagan, J. (1954). The critical incident technique. Psychological Bulletin 51 (4), 327-358.

Hallituksen esitys 2017. Hallituksen esitys eduskunnalle laiksi ammatillisesta koulutuksesta ja eräiksi siihen liittyviksi laeiksi, 39. Opetus- ja kulttuuriministeriö. http://minedu.fi/paatos?decisionld=0900908f805 2b569 (26.4.2017).

Hakkarainen, K., Lonka, K. \& Lipponen, L. (2004). Tutkiva oppiminen. Järki, tunteet ja kulttuuri oppimisen sytyttäjänä. Porvoo: WS Bookwell Oy.

Hulkari, K. (2006). Työssäoppimisen laadun käsite, itsearviointi ja kehittäminen sosiaali- ja terveysalan ammatillisessa peruskoulutuksessa. Tampere: Tampereen Yliopistopaino Oy - Juvenes Print.

Hammersley, M. (2013). What is Qualitative Research? London: Bloomsbury Publishing Plc.

Jensen, J. L. \& Rodgers, R. (2001). Cumulating the intellectual gold of case study research. Public Administration Review 61 (2), 236-246.

Jordan, A., Carlile, O. \& Stack, A. (2008). Approaches to Learning. A Guide for Teachers. England, Berkshire: The McGraw-Hill Companies, Open University Press.

Keisala, K. (2012). Monikulttuurisen työyhteisön viestintä. Tampere: Tampere University Press.

Kinnunen, T. (2018). Ammatillisesta opetuksesta katosivat opettajat. https://yle.fi/uutiset/3-10333832 (11.8.2018)

Laki ammatillisesta koulutuksesta 2017/531. Annettu Naantalissa 11.8.2017. https://www.finlex.fi/fi/laki/ alkup/2017/20170531 (25.2.2018).

Lave, J. (1996). Teaching as learning in practice. Mind, Culture, and Activity 3 (3), 149-164.

Lave, J. \& Wenger, E. (1991). Situated Learning: Legitimate Peripheral Participation. Cambridge: Cambridge University Press.
Marton, F. (1996). Cognosco ergo sum: Reflections on Reflections. Teoksessa Dall'Alba, G. \& Hasselgreen, B. (toim.) Reflections on Phenomenography: Toward a Methodology? Göteborg: University of Göteborg, 163-187.

Nissilä, S.-P., Karjalainen, A., Koukkari, M. \& Kepanen, P. (2015). Towards competence-based practics in vocational education - what will the process require from teacher education and teacher identities? Center for Educational Policy Studies Journal, 5, 13-34.

Näyttötutkinnon perusteet 2013. Laitoshuoltajan ammattitutkinto. Määräys 12/011/2013. Helsinki: Opetushallitus.

Ojanen, S. (2000). Ohjauksesta oivallukseen Ohjausteorian kehittelyä. Helsinki: Palmenia.

Rauste-von Wright, M., von Wright, J. \& Soini, T. (2003). Oppiminen ja koulutus. (9. uudistettu painos.) Helsinki: WSOY.

Rintala, H., Mikkonen, S., Pylväs, L., Nokelainen, P. \& Postareff, L. (2015). Työpaikalla tapahtuvaa oppimista ja ohjausta estävät ja edistävät tekijät. Ammattikasvatuksen aikakauskirja 17 (4), 9-61.

Räty, K. (2016). Erityinen tuki elinikäisen oppimisen mahdollistajana ammatillisessa aikuiskoulutuksessa. Helsingin yliopisto. Käyttäytymistieteellinen tiedekunta. Väitöskirja.

Salusjärvi, K. (2017). Ammattikouluissa on käynnissä vaarallinen ihmiskoe. https://yle.fi/uutiset/3-9828737 (12.8.2018)

Samppala, M.-L. (2017). Käsityksiä ja kokemuksia laitoshuoltajaopiskelijoiden oppimisesta työpaikalla. Helsingin yliopisto. Kasvatustieteellisiä tutkimuksia, numero 12. Väitöskirja.

Tuomi-Gröhn, T. (2001). Kehittävä siirtovaikutus koulun ja työpaikan yhteistyön tavoitteena - tapaustutkimus lähihoitajien lisäkoulutuksesta. Teoksessa TuomiGröhn, T. \& Engeström, Y. (toim.) Koulun ja työn rajavyöhykkeellä. Uusia työssä oppimisen mahdollisuuksia. Helsinki: Yliopistopaino, 28-66.

Virkkula, E. (2014). "Soittaminen ammattilaisen kanssa on paras tapa oppia". Työpajaperustainen työssäoppiminen muusikoiden ammatillisessa koulutuksessa. Tampere: Juvenes Print.

Virtanen, A. \& Collin, K. (2007). Työssäoppiminen ammatillisessa peruskoulutuksessa. Teoksessa Eteläpelto, A., Collin, K. \& Saarinen, J. (toim.) Työ, identiteetti ja oppiminen. Helsinki: WSOY, 216-235.

Vågan, A. (2011). Towards a sociocultural perspective on identity formation in education. Mind, Culture, and Activity 18 (1), 43-57. 